\title{
Nebulised water as a bronchoconstricting challenge in infancy
}

\author{
Christopher O'Callaghan, A D Milner, M S C Webb, A Swarbrick
}

\begin{abstract}
The pulmonary response to inhalation challenge with nebulised distilled water was measured in 100 sedated infants with a history of wheeze. Lung function was measured by total body plethysmography. Satisfactory results were obtained in 88 infants. Fifty one were considered to have responded by developing a greater than $20 \%$ decrease in specific conductance (sGaw) after nebulised water. Thirty two of these infants had previously been challenged with nebulised saline before but only one showed a greater than $20 \%$ decrease in sGaw after saline.

Twenty infants who developed signs of bronchoconstriction after challenge with nebulised water were rechallenged 20 minutes later. After the initial challenge a fall in sGaw of greater than $20 \%$ was found in 19 of the 20 . After a second challenge with nebulised water only $15(75 \%)$ showed a $20 \%$ or greater decrease in sGaw. Nine of the 20 infants remained sedated and were rechallenged for a third time. Eight showed a greater than $20 \%$ decrease in sGaw.

This study indicates that approximately $60 \%$ of infants with a history of wheeze will bronchoconstrict in response to inhaled nebulised water and that up to $75 \%$ show no evidence of a subsequent refractory period to inhaled water challenge.
\end{abstract}

Lower respiratory tract illness, such as bronchiolitis $^{1}$ and chlamydial pneumonia, ${ }^{2}$ are associated with high prevalence rates of bronchial hyper-reactivity in future years. Understanding the airway response to pulmonary insults in the first year of life may help to determine the pathogenesis of reactive airways disease. Studies on the effect of antiasthma drugs on airway reactivity provide information on mechanisms occurring in asthma and are helpful in the assessment of new techniques. Histamine, ${ }^{3}$ methacholine, ${ }^{4}$ and cold dry air ${ }^{5}$ challenges all produce bronchoconstriction in infancy. Nebulised water has previously been shown to be an effective bronchoprovocative agent in asthmatic adults ${ }^{6}$ and older children. ${ }^{7}$

To study the effects of antiasthma drugs we planned to give infants nebulised water as a bronchoconstricting challenge, administer either a $\beta_{2}$ agonist $^{8}$ or sodium cromoglycate, and rechallenge with nebulised water. It was necessary to determine first whether any lack of response to the second nebulised water challenge was due to the drug exerting a protective effect or due to a refractory period after the initial challenge.

The aim of this study therefore was to determine the effect of repeated challenges with nebulised water on infants with a history of recurrent wheezing. The 20 infants in this study were chosen from 100 infants challenged with nebulised water. To illustrate how the 20 infants were chosen the results of all 100 patients are discussed briefly.

\section{Methods}

All patients had had at least two episodes of wheeze in the preceeding two months. All but nine of the patients had been seen during an episode of wheeze by one of the authors.

Once sedated with chloral hydrate (120 $\mathrm{mg} / \mathrm{kg}$ ) each infant was placed in the total body plethysmograph and allowed to settle for several minutes. Baseline lung function (thoracic gas volume and airway resistance) was then measured.

Thirty two of the infants were given ultrasonically nebulised saline $(0.9 \%)$ from an intersurgical Variosonic nebuliser $\left(21^{\circ} \mathrm{C}\right.$, volume fill $150 \mathrm{ml}$, setting 3, via an airtight latex mask for two minutes at a flow rate of $5 \mathrm{l} /$ minute). After nebulisation, readings were taken for calculation of thoracic gas volume and airway resistance at regular intervals (every 2-3 minutes) until readings were back to a stable baseline. Results were determined as back to baseline when there was minimal changes (less than $0.5^{\circ}$ ) in the slope of the box pressure/slope readings from the face of the oscilloscope over a 5-6 minute period.

One hundred infants were then given ultrasonically nebulised water from the same nebuliser $\left(21^{\circ} \mathrm{C}\right.$, volume fill $150 \mathrm{ml}$, setting 3$)$ for two minutes. Again readings were taken for thoracic gas volume and airway resistance at 2-3 minute intervals until readings had become stable.

Twenty of these patients were selected for repeated water challenge when the pressure/flow slope on the face of the oscilloscope changed after the initial nebulised water challenge and was judged by the observer to indicate increased airway resistance. The 20 infants (13 boys and seven girls) studied had a mean (SD) age of 9 (3) months and had suffered from at least two episodes of wheeze in the preceeding months. The mean (SD) weight of the group was $9 \cdot 1$ $(1 \cdot 2) \mathrm{kg}$.

The 20 infants selected were rechallenged with nebulised water 20 minutes after the first 


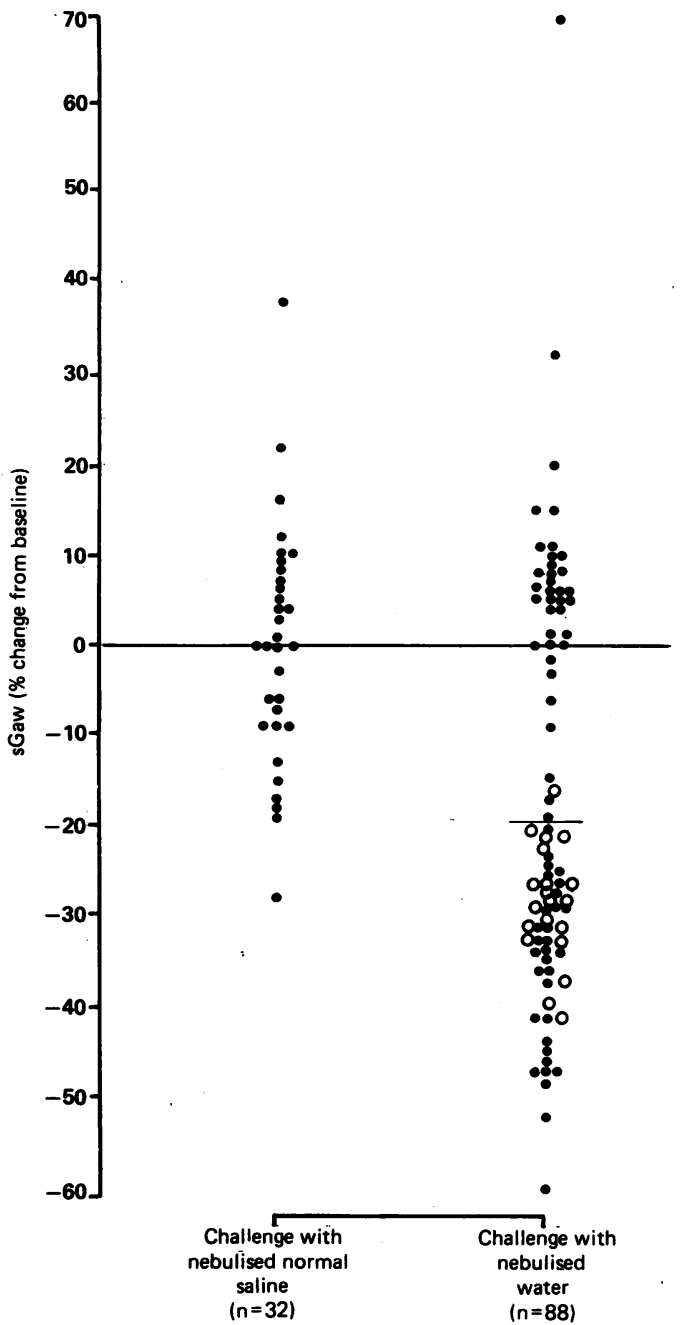

Figure 1 Percentage change from baseline of specific conductance in infants challenged with nebulised water and normal saline. Open circles denote infants selected for further challenge with nebulised water.

nebulised water challenge. Again readings for calculation of thoracic gas volume and airway resistance were taken every 2-3 minutes until they had reached a steady baseline. Of the 20 infants rechallenged with nebulised water, 11 had received an initial challenge with nebulised saline. Nine infants remaining asleep after the second nebulised water challenge were rechallenged with nebulised water for a third time. Patients had electrocardiographic and oxygen saturation monitoring during the study.

Table 1 Nebulised normal saline:baseline lung function before and sGaw after challenge in 11 infants

\begin{tabular}{|c|c|c|c|c|c|}
\hline \multirow{2}{*}{$\begin{array}{l}\text { Patient } \\
\text { No }\end{array}$} & \multirow{2}{*}{$\begin{array}{l}\text { Airway } \\
\text { resistance } \\
\left(\mathrm{cmH}_{2} \mathrm{O} / \mathrm{l} / \mathrm{s}\right)\end{array}$} & \multicolumn{2}{|l|}{ Baseline readings } & \multirow{2}{*}{$\begin{array}{l}\text { sGaw after } \\
\text { challenge } \\
\left(/ \mathrm{s} / \mathrm{cmH}_{2} \mathrm{O}\right)\end{array}$} & \multirow{2}{*}{$\begin{array}{l}\text { \% Change in } \\
\text { sGaw from } \\
\text { baseline }\end{array}$} \\
\hline & & $\begin{array}{l}\text { Thoracic gas } \\
\text { volume (ml/kg) }\end{array}$ & $\begin{array}{l}\text { sGaw } \\
\left(/ \mathrm{s} / \mathrm{cmH}_{2} \mathrm{O}\right)\end{array}$ & & \\
\hline $\begin{array}{r}1 \\
2 \\
3 \\
4 \\
5 \\
6 \\
7 \\
8 \\
9 \\
10 \\
11\end{array}$ & $\begin{array}{l}22 \\
17 \\
21 \\
24 \\
15 \\
25 \\
15 \\
14 \\
14 \\
34 \\
26\end{array}$ & $\begin{array}{l}30 \\
39 \\
38 \\
24 \\
27 \\
43 \\
30 \\
30 \\
28 \\
30 \\
33\end{array}$ & $\begin{array}{l}0.15 \\
0.20 \\
0.11 \\
0.18 \\
0.27 \\
0.15 \\
0.16 \\
0.16 \\
0.21 \\
0.13 \\
0.14\end{array}$ & $\begin{array}{l}0.13 \\
0.22 \\
0.09 \\
0.21 \\
0.25 \\
0.15 \\
0.15 \\
0.15 \\
0 \cdot 19 \\
0.13 \\
0.15\end{array}$ & $\begin{array}{r}-13 \\
-10 \\
-18 \\
16 \\
-7 \\
0 \\
-6 \\
-6 \\
-9 \\
0 \\
7\end{array}$ \\
\hline
\end{tabular}

CALIBRATION OF NEBULISER

The mass median diameter of the nebulised water aerosol and the nebulised saline aerosol were determined using a Malvern laser particle size analyser (Malvern Instruments model 3600).

The nebulised aerosol passed through $56 \mathrm{~cm}$ of plastic tubing before reaching the face mask of the child. An exact replica of this was built including bends and was fitted to the nebuliser to simulute in vivo conditions. The nebuliser was run for two minutes and the nebuliser cloud pulled across the laser beam of the Malvern device by single stage impacter, run at a flow rate of $60 \mathrm{l} /$ minute. The output of the nebuliser was calculated by weighing the nebuliser and the tubes before and after nebulisation. Each reading was repeated on eight occasions. Calibration of the nebuliser was rechecked after the study had been in progress for six months.

A paired $t$ test was used to analyse results. Ethical approval was given by the Nottingham Hospitals ethical committee and informed parental consent was obtained for the studies.

\section{Results}

Technically satisfactory results were obtained in 88 of the original 100 infants. The percentage change in specific conductance (sGaw) from baseline after challenge with nebulised water in the 88 infants is shown in fig 1 . After nebulised water 51 infants showed a greater than $20 \%$ decrease and only three showed a greater than $20 \%$ increase in sGaw. The effect of nebulised saline on lung function is also included. Of the 32 infants challenged with nebulised normal saline only one showed a decrease in sGaw of greater than $20 \%$.

This paper concentrates on the 20 infants who were chosen for rechallenge with nebulised water. Eleven of the 20 infants had been challenged with nebulised normal saline. Baseline lung function before and after challenges is shown in tables $1-4$. There was no significant difference between the baseline readings and those after nebulised normal saline. Also none of these infants showed a greater than $20 \%$ change from baseline sGaw after normal saline. The 11 infants challenged with nebulised saline showed a significant decrease in sGaw after challenge with nebulised water $(p<0.01)$.

All but one of the 20 infants showed a $20 \%$ decrease in sGaw after initial water challenge (fig 2). After the second challenge five of the 20 infants showed a less than $20 \%$ change in sGaw (fig 2). All other infants showed at least a $20 \%$ decrease in sGaw after the second nebulised water challenge. Of the nine infants who stayed asleep to allow a third challenge all but one showed a $20 \%$ decrease in sGaw.

There was a small decrease in mean (SD) baseline sGaw between the first $(0 \cdot 19$ $\left.(0.05) / \mathrm{s} / \mathrm{cmH}_{2} \mathrm{O}\right)$ and the second water challenge $\left(0.18(0.05) / \mathrm{s} / \mathrm{cmH}_{2} \mathrm{O}\right)$ and the third challenge $\left(0 \cdot 17(0.04) / \mathrm{s} / \mathrm{cmH}_{2} \mathrm{O}\right)$.

The mass median diameter of the normal saline and nebulised water aerosol were 5.0 and $4.8 \mu \mathrm{m}$ respectively (geometric SD 1.7 and $1 \cdot 8$ ). The mean (SD) output per minute of the normal saline and nebulised water aerosol was 
Table 2 First nebulised water challenge:baseline lung function before and sGaw after challenge in 20 infants

\begin{tabular}{|c|c|c|c|c|c|}
\hline \multirow{2}{*}{$\begin{array}{l}\text { Patient } \\
\text { No }\end{array}$} & \multirow{2}{*}{$\begin{array}{l}\text { Airway } \\
\text { resistance } \\
\left(\mathrm{cmH}_{2} \mathrm{O} / \mathrm{l} / \mathrm{s}\right)\end{array}$} & \multicolumn{2}{|l|}{ Baseline readings } & \multirow{2}{*}{$\begin{array}{l}\text { sGaw after } \\
\text { challenge } \\
\left(/ \mathrm{s} / \mathrm{cmH}_{2} \mathrm{O}\right)\end{array}$} & \multirow{2}{*}{$\begin{array}{l}\% \text { Change in } \\
\text { sGaw from } \\
\text { baseline }\end{array}$} \\
\hline & & $\begin{array}{l}\text { Thoracic gas } \\
\text { volume (ml/kg) }\end{array}$ & $\begin{array}{l}\text { sGaw } \\
\left(/ \mathrm{s} / \mathrm{cmH}_{2} \mathrm{O}\right)\end{array}$ & & \\
\hline $\begin{array}{r}1 \\
2 \\
3 \\
4 \\
5 \\
6 \\
7 \\
8 \\
9 \\
10 \\
11 \\
12 \\
13 \\
14 \\
15 \\
16 \\
17 \\
18 \\
19 \\
20\end{array}$ & $\begin{array}{l}22 \\
16 \\
21 \\
23 \\
15 \\
18 \\
15 \\
20 \\
19 \\
39 \\
26 \\
16 \\
26 \\
21 \\
27 \\
16 \\
16 \\
25 \\
22 \\
21\end{array}$ & $\begin{array}{l}28 \\
39 \\
38 \\
24 \\
27 \\
31 \\
20 \\
31 \\
28 \\
30 \\
33 \\
32 \\
32 \\
37 \\
33 \\
27 \\
26 \\
31 \\
37 \\
28\end{array}$ & $\begin{array}{l}0 \cdot 15 \\
0 \cdot 22 \\
0 \cdot 11 \\
0 \cdot 19 \\
0 \cdot 25 \\
0 \cdot 16 \\
0 \cdot 30 \\
0 \cdot 16 \\
0 \cdot 22 \\
0 \cdot 13 \\
0 \cdot 15 \\
0 \cdot 19 \\
0 \cdot 24 \\
0 \cdot 13 \\
0 \cdot 12 \\
0 \cdot 25 \\
0 \cdot 24 \\
0 \cdot 14 \\
0 \cdot 16 \\
0 \cdot 18\end{array}$ & $\begin{array}{l}0.11 \\
0.15 \\
0.08 \\
0.14 \\
0.18 \\
0.10 \\
0.21 \\
0.11 \\
0.13 \\
0.11 \\
0.11 \\
0.15 \\
0.19 \\
0.10 \\
0.08 \\
0.17 \\
0.15 \\
0.11 \\
0.10 \\
0.13\end{array}$ & $\begin{array}{l}-26 \\
-31 \\
-27 \\
-27 \\
-28 \\
-37 \\
-30 \\
-32 \\
-41 \\
-16 \\
-26 \\
-21 \\
-20 \\
-23 \\
-26 \\
-32 \\
-40 \\
-21 \\
-31 \\
-28\end{array}$ \\
\hline
\end{tabular}

Table 3 Second nebulised water challenge:baseline lung function before and sGaw after challenge in 20 infants

\begin{tabular}{|c|c|c|c|c|c|}
\hline \multirow{2}{*}{$\begin{array}{l}\text { Patient } \\
\text { No }\end{array}$} & \multirow{2}{*}{$\begin{array}{l}\text { Airway } \\
\text { resistance } \\
\left(\mathrm{cmH}_{2} \mathrm{O} / \mathrm{ll} / \mathrm{s}\right)\end{array}$} & \multicolumn{2}{|l|}{ Baseline readings } & \multirow{2}{*}{$\begin{array}{l}\text { sGaw after } \\
\text { challenge } \\
\left(/ \mathrm{s} / \mathrm{cmH}_{2} \mathrm{O}\right)\end{array}$} & \multirow{2}{*}{$\begin{array}{l}\% \text { Change in } \\
\text { sGaw from } \\
\text { baseline }\end{array}$} \\
\hline & & $\begin{array}{l}\text { Thoracic gas } \\
\text { volume (ml/kg) }\end{array}$ & $\begin{array}{l}\text { sGaw } \\
\left(/ \mathrm{s} / \mathrm{cmH}_{2} \mathrm{O}\right)\end{array}$ & & \\
\hline $\begin{array}{l}1 \\
2 \\
3 \\
4 \\
5 \\
6 \\
7 \\
8 \\
9 \\
10 \\
11 \\
12 \\
13 \\
14 \\
15 \\
16 \\
17 \\
18 \\
19 \\
20\end{array}$ & $\begin{array}{l}21 \cdot 5 \\
22 \\
21 \\
27 \\
17 \\
22 \\
13 \\
20 \\
22 \\
36 \\
27 \\
18 \\
26 \\
18 \\
28 \\
16 \\
26 \\
23 \\
25 \\
23\end{array}$ & $\begin{array}{l}31 \\
34 \\
36 \\
23 \\
27 \\
28 \\
20 \\
32 \\
27 \\
28 \\
31 \\
32 \\
17 \\
35 \\
32 \\
27 \\
27 \\
31 \\
37 \\
27\end{array}$ & $\begin{array}{l}0.15 \\
0.15 \\
0.11 \\
0.17 \\
0.23 \\
0.16 \\
0.33 \\
0.15 \\
0.21 \\
0.13 \\
0.14 \\
0.17 \\
0.26 \\
0.15 \\
0.12 \\
0.24 \\
0.14 \\
0.16 \\
0.14 \\
0.18\end{array}$ & $\begin{array}{l}0.12 \\
0.14 \\
0.08 \\
0.16 \\
0.21 \\
0.10 \\
0.23 \\
0.10 \\
0.12 \\
0.10 \\
0.11 \\
0.12 \\
0.19 \\
0.10 \\
0.06 \\
0.25 \\
0.10 \\
0.12 \\
0.10 \\
0.13\end{array}$ & $\begin{array}{r}-14 \\
-6 \\
-28 \\
-6 \\
-8 \\
-27 \\
-37 \\
-33 \\
-40 \\
-24 \\
-26 \\
-29 \\
-27 \\
-23 \\
-50 \\
5 \\
-29 \\
-25 \\
-29 \\
-28\end{array}$ \\
\hline
\end{tabular}

Table 4 Third nebulised water challenge:baseline lung function before and sGaw after challenge in nine infants

\begin{tabular}{|c|c|c|c|c|c|}
\hline \multirow{2}{*}{$\begin{array}{l}\text { Patient } \\
\text { No }\end{array}$} & \multirow{2}{*}{$\begin{array}{l}\text { Airway } \\
\text { resistance } \\
\left(\mathrm{cmH}_{2} \mathrm{O} / \mathrm{ll} / \mathrm{s}\right)\end{array}$} & \multicolumn{2}{|l|}{ Baseline readings } & \multirow{2}{*}{$\begin{array}{l}\text { sGaw after } \\
\text { challenge } \\
\left(/ \mathrm{s} / \mathrm{cmH} \mathrm{H}_{2} \mathrm{O}\right)\end{array}$} & \multirow{2}{*}{$\begin{array}{l}\% \text { Change in } \\
\text { sGaw from } \\
\text { baseline }\end{array}$} \\
\hline & & $\begin{array}{l}\text { Thoracic gas } \\
\text { volume (ml/kg) }\end{array}$ & $\begin{array}{l}\mathrm{s} G a w \\
\left(/ \mathrm{s} / \mathrm{cmH}_{2} \mathrm{O}\right)\end{array}$ & & \\
\hline $\begin{array}{r}6 \\
7 \\
8 \\
9 \\
10 \\
11 \\
18 \\
19 \\
20\end{array}$ & $\begin{array}{l}22 \\
15 \\
21 \\
22 \\
36 \\
27 \\
25 \\
23 \\
23\end{array}$ & $\begin{array}{l}28 \\
20 \\
33 \\
27 \\
28 \\
31 \\
32 \\
37 \\
27\end{array}$ & $\begin{array}{l}0 \cdot 16 \\
0.3 \\
0 \cdot 16 \\
0 \cdot 2 \\
0 \cdot 13 \\
0 \cdot 17 \\
0 \cdot 14 \\
0 \cdot 15 \\
0 \cdot 18\end{array}$ & $\begin{array}{l}0 \cdot 12 \\
0 \cdot 23 \\
0 \cdot 11 \\
0 \cdot 1 \\
0 \cdot 12 \\
0 \cdot 11 \\
0 \cdot 11 \\
0 \cdot 11 \\
0 \cdot 12\end{array}$ & $\begin{array}{r}-25 \\
-24 \\
-31 \\
-50 \\
-9 \\
-36 \\
-22 \\
-27 \\
-34\end{array}$ \\
\hline
\end{tabular}

$1.7(0)$ and $1.9(0) \mathrm{g} /$ minute respectively. There was no significant change in nebuliser output and particle size when measured six months after initial calibration.

\section{Discussion}

Bronchoconstriction after nebulised water has been demonstrated in asthmatic children and adults and it has been found to be a sensitive and highly specific test for bronchial reactivity in asthmatic patients. ${ }^{9}$ This study demonstrates

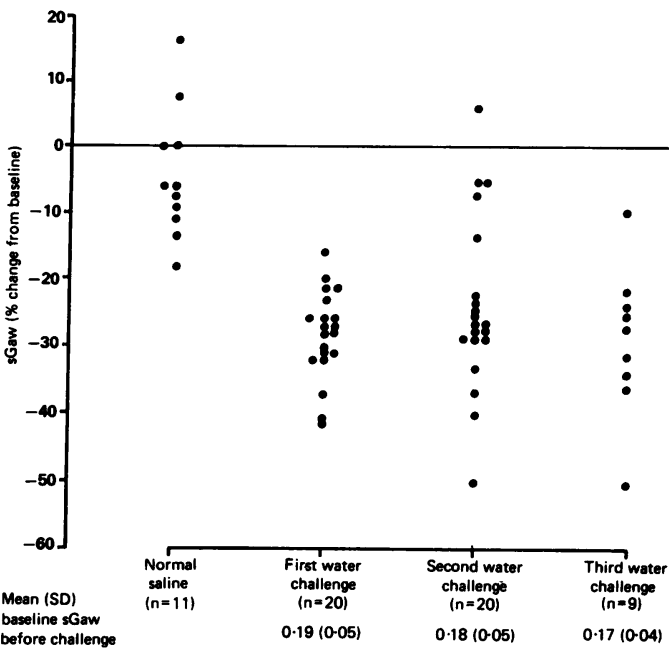

Figure 2 Percentage change from baseline of specific conductance after challenges with nebulised normal saline and water. Mean baseline specific conductance $\left(/ \mathrm{s} / \mathrm{cmH}_{2} \mathrm{O}\right)$ before each challenge is also shown.

that nebulised water may also cause bronchoconstriction in infants with a history of wheeze.

Where as no cut off is ideal for determining bronchial hyper-responsiveness we have chosen a decrease in sGaw of greater than $20 \%$ to be significant. This is based on results from a separate study where infants were repositioned while in the total body plethysmograph and lung function measured before and after. This gave an intrasubject coefficient of variation for sGaw of $10 \%$. Therefore a change of greater than $20 \%$ is greater than twice the coefficient of variation of intrasubject change in specific conductance. Also in our study none of the 32 patients who were given nebulised saline had a decrease in sGaw of greater than $20 \%$.

The aim of this study was to determine if wheezy infants were refractory to repeated nebulised water challenge. To determine the effect of antiasthma drugs it is important to know whether lack of bronchoconstriction after a further water challenge could be explained by a refractory period. The results of the 88 infants challenged with nebulised water were shown to indicate how the 20 infants were chosen. We do not feel we can analyse the results of the total group further. During our study period we found that it was impossible to say whether the infant was breathing through one of its nostrils, both of its nostrils, through its mouth, or both nostrils and mouth. Thus the delivery of aerosol to each infant may have been considerably different. We are now developing an accurate dosimetric technique for infant challenge studies. It appears from the study that $75 \%$ of our infants are not refractory to a second water challenge. It was interesting that eight of the nine infants who were challenged on the third occasion also showed greater than $\mathbf{2 0 \%}$ decrease in sGaw. There was an overall decrease in baseline sGaw between challenges indicating a worsening of lung function through progressive challenge. This may have enhanced the effect of nebulised water in later challenges. Because resistance to airflow increases inversely with the 4th power of the radius, the response to 
bronchoconstrictor stimuli could have a dramatically greater effect on the airflow resistance in smaller airways of infants. In addition repeated challenge over a short period may have enhanced the bronchoconstrictor response by progressively decreasing the osmolality of fluid lining the airway. Lack of a consistent refractory period after nebulised water challenge has also been found by Mattolli et $a l^{10}$ and Anderson et al..$^{11}$

Only 11 of the 20 infants undergoing multiple nebulised water challenges were challenged with nebulised saline before nebulised water challenge. Ideally all 20 should have been challenged with nebulised normal saline. However we elected not to challenge nine of the infants with nebulised saline as this increased the study time and we had by then found that none of the initial 11 infants studied had shown a decrease in sGaw of greater than $20 \%$ after nebulised saline.

By measuring the slope of the mask pressure/ box pressure trace and change in box pressure/ flow trace it was possible to make multiple measurements and calculate airway resistance, thoracic gas volume, and sGaw during the study. Although measurements directly from the screen of the oscilloscope have been criticised, we feel that used in this context change in sGaw acts as a valid measurement to compare changes in lung function with repeated challenge.

The reproducibility of change in sGaw after nebulished water challenges was remarkably good. Because of this, observer bias needs to be considered and indeed the same observer made all of the readings and was aware of which challenges were being administered. However, during the study period a separate observer checked several of the readings. The second observer consistently underestimated the sGaw determined by the first observer by a mean of $15 \%$.

The only conclusions that may be drawn from this study are that nebulised water may cause bronchoconstriction in infants with a history of wheeze and up to $75 \%$ of these infants show evidence of bronchoconstriction when rechallenged with a similar amount of nebulised water shortly afterwards.

We would like to thank the Mason Medical Foundation and the National Asthma Campaign for their support.

1 Pullan CR, Hey EN. Wheezing, asthma and pulmonary dysfunction ten years after infection with respiratory dysfunction ten years after infection with respi
syncytial virus in infancy. $B M \mathcal{F} 1982 ; 284: 1665-9$.

2 Weiss SG, Newcomb RW, Beem MD. Pulmonary assessment of children after chlamydial pneumonia of infancy. f Pediatr 1986;108:659-64.

3 Prendiville A, Green S, Silverman M. Bronchial responsiveness to histamine in wheezing infants. Thorax 1987;42: 92-9.

4 Tepper RS. Airways reactivity in infants: a positive response to metacholine and metaproterenol. $\mathcal{F}$ Appl Physiol 1987; 62:1155-9.

5 Geller DE, Morgan WJ, Cota KA, Wright AL, Taussig LM. Airway responsiveness to cold, dry air in normal infants. Pediatric Pulmonol 1988;4:90-7.

6 Schoeffel RE, Anderson SD, Altoonyan RG. Bronchial hyper-reactivity in response to inhalation of ultrasonically hyper-reactivity in response to inhalation of ultrasonically
nebulised solutions of distilled water and saline. $B M \mathcal{F}$ 1981;283:1285-7.

7 Barker R, Levison H. Effects of ultrasonically nebulised distilled water on airway dynamics in children with cystic distilled water on airway dynamics in children with

8 O'Callaghan C, Milner AD, Swarbrick A. Paradoxical deterioration in lung function after nebulised salbutamol in wheezy infants. Lancet 1986;ii:1424-5.

9 Galdes-Seboldt M, McLaughlin FJ, Levison LT. Comparison of cold air, ultrasonic mist and methacholine inhalations as tests of bronchial reactivity in normal and asthmatic children. $\mathcal{F}$ Pediatr 1985;107:526-9.

10 Mattoli S, Foresi A, Cobra GM, Valente S, Polotons F, Ciappi G. Increased bronchial responsiveness to methacholine and late asthmatic response after the inhalation of ultrasonically nebulised distilled water. Chest 1986;90: 726-32.

11 Anderson SD, Schoeffel RE, Finney M. Evaluation of ultrasonically nebulised solutions for provocation testing in patients with astham. Thorax 1983;38:284-91. 